\title{
Potential inundation of Lisbon downtown by a 1755-like tsunami
}

\author{
M. A. Baptista ${ }^{1,2}$, J. M. Miranda ${ }^{1}$, R. Omira ${ }^{1,3}$, and C. Antunes ${ }^{1}$ \\ ${ }^{1}$ Instituto D Luiz, Rua Ernesto de Vasconcelos, campus FCUL, C8, 3 , 1749-016 Lisboa, Portugal \\ ${ }^{2}$ Instituto Superior de Engenharia de Lisboa, Rua Conselheiro Emidio Navarro, 1, 1749-077 Lisboa, Portugal \\ ${ }^{3}$ Instituto de Meteorologia, Rua C do Aeroporto de Lisboa, 1900 Lisboa, Portugal
}

Received: 10 July 2011 - Revised: 12 September 2011 - Accepted: 13 September 2011 - Published: 16 December 2011

\begin{abstract}
In this study, we present $10 \mathrm{~m}$ resolution tsunami flooding maps for Lisbon downtown and the Tagus estuary. To compute these maps we use the present bathymetry and topographic maps and a reasonable estimate for the maximum credible tsunami scenario. Tsunami modeling was made with a non-linear shallow water model using four levels of nested grids. The tsunami flood is discussed in terms of flow depth, run-up height and maximum inundation area. The results show that, even today, in spite of the significant morphologic changes in the city river front after the 1755 earthquake, a similar event would cause tsunami flow depths larger than one meter in a large area along the Tagus estuary and Lisbon downtown. Other areas along the estuary with a high population density would also be strongly affected. The impact of the tide on the extent of tsunami inundation is discussed, due to the large amplitude range of the tide in Lisbon, and compared with the historical descriptions of the 1755 event. The results presented here can be used to identify the potential tsunami inundation areas in Lisbon; this identification comprises a key element of the Portuguese tsunami emergency management system.
\end{abstract}

\section{Introduction}

Large tsunamis described in Portuguese historical accounts come always associated with strong magnitude earthquakes.

The most destructive tsunamis in the Tagus Estuary were observed on the 26 January 1531, a local tsunami event, and the two transoceanic events of 1 November 1755 and 31 March 1761 (Baptista et al., 2006). Only two events are believed to have been generated inside the estuary: the 26 January 1531 and the 18 December 1926 (Baptista and

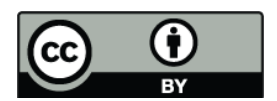

Correspondence to: M. A. Baptista (mavbaptista@gmail.com)
Miranda, 2009) although their source mechanism is still unknown. The events dated $60 \mathrm{BC}, 382 \mathrm{AD}, 1755,1761$ and 1969 (Baptista and Miranda, 2009) (see Fig. 1a) are related to the compressive tectonic regime of the South West Iberian margin.

Two events caused severe flooding of downtown Lisbon: the 1531 event, with the earthquake epicentre located NW of Lisbon, upriver, and the 1 November 1755, with epicentre located offshore, somewhere in the SW Portuguese margin. The 1755 earthquake generated a transoceanic tsunami seriously impacting the Iberian Peninsula and North Atlantic Morocco, with far-field effects in the United Kingdom (to the north) and the Caribbean Islands (to the SW). This tsunami was the worst historical event for Portugal; in Lisbon the number of casualties due exclusively to the tsunami was close to one thousand and the maximum inundation distance estimate is $250 \mathrm{~m}$ (Baptista et al., 1998a).

In order to reconstruct what happened on the morning of 1 November 1755, we selected the descriptions of the tsunami in places that still exist today: the castles of Bugio (BC) and São Julião (SJ) (see Fig. 1b). This is the case of the castle of Bugio described in the Gentleman's Magazine of December 1755: “[...] Its entrance (Lisbon) is defended by two fortresses; the first one called São Julião is built on shore, the other one, the Castle of Bugio, stands opposite, on a bank surrounded by water..." (Urban, 1755a).

The description of the tsunami entering the Tagus estuary in a letter dated 19 November 1755 published in the Gentleman's Magazine (Urban, 1755b): "[... ] I observed the sea at the Bar to break feather white, as if agitated in a storm. Castle of Bugio was so far overcome by the water, that the garrison fired several guns as signals for help, and were obliged to retire to the upper part of the tower. By my best judgment, the water rose in five minutes about 16 feet, and fell in the same time for three times, and at two the tide returned to its natural course". From this report, we can infer the amplitude at Bugio to be fixed as nearly $5 \mathrm{~m}$. 


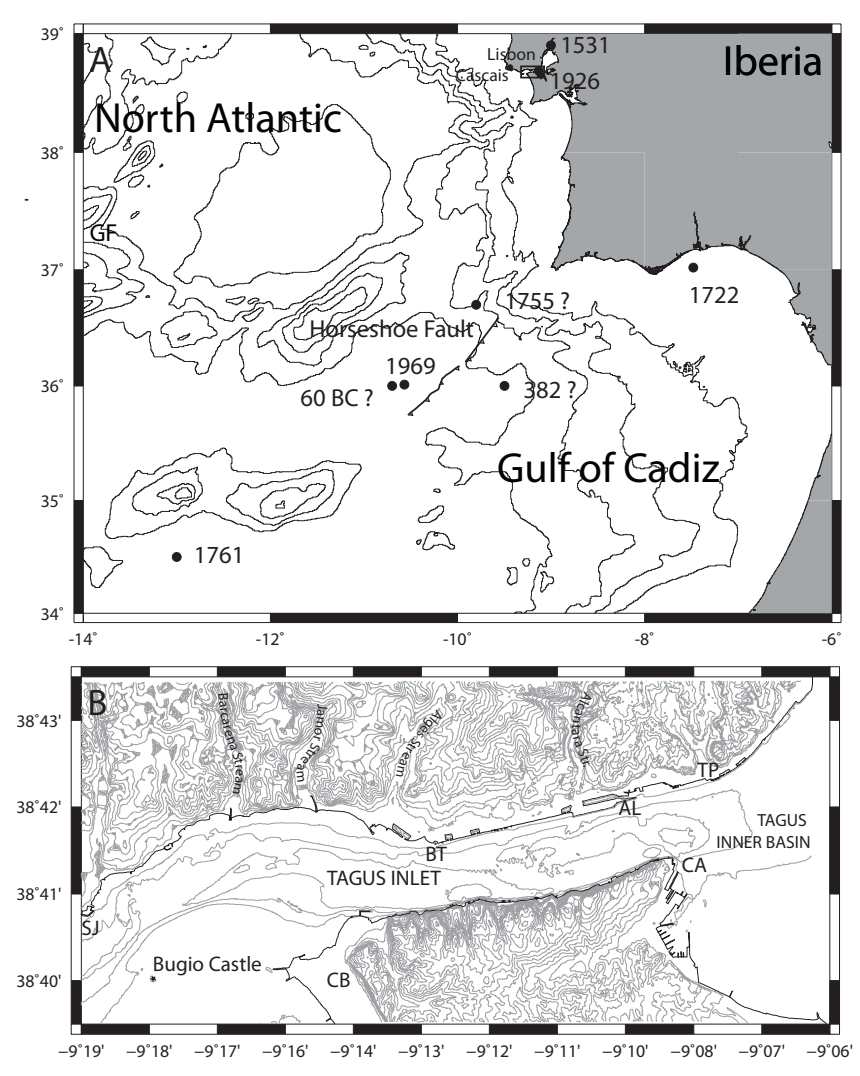

Fig. 1. (A) The study area (Lisbon riverfront, represented by a solid rectangle) is located inside the Tagus Estuary, in western Iberia. Major historic tsunami sources are plotted in their approximate locations. (B) Bathymetry and topography of the study area are plotted every $10 \mathrm{~m}$. The coastline is punctuated by a succession of quays and piers. BC (Bugio Castle), BT (Belem Tower), TP (Terreiro do Paço), CB (Caparica Beach), CA (Cacilhas), SJ (São Julião).

Along the estuary, other descriptions reinforce the observation made at Bugio: "[...] But this dismal earthquake had such an influence upon the sea and the river that the water rose in about ten minutes several yards perpendicular (Urban, 1755c); "[...] the bar was seen dry from shore to shore, then suddenly the sea like a mountain came rolling in, and about Bellem the water rose 50 feet in an instant, and had it not been for the great bay to receive and spread the great flux, the low part of the city must have been under water (Urban, 1755b); “[...] Indeed every element seemed to conspire to our destruction; for soon after the shock, which was near high water, the tide rose forty feet higher in an instant than was ever known, and suddenly subsided [...]" (Wolsall, 1756). The flooding of the city is described in various reports and from those we can infer inundation distances and estimated flow depths: "[...] suddenly the sea enters the bar with furious flooding waters [...] overcoming its ordinary limits overtopped some buildings and flooded the quartier of São Paulo (Mendonça, 1758); “[... ]... It (the sea) came on foaming and roaring, and rushed towards the shore... many were actually swept away. The rest were above their waist in water, a good distance from the banks..." (Anonymous, 1755).

Since the XVI century, the Tagus has suffered significant morphological modifications. These changes were particularly influential after the construction of the Tower of Belem (BT in Fig. 1b) and Bugio Castle, significantly enhancing the sedimentation along the northern margin of the river. One consequence of this process is the relative location of the Tower of Belem, initially off-shore and bordering to the south a channel deep enough to anchor the large vessels that used to navigate to India and America, and nowadays on the river beach. At the time of the 1755 earthquake, most of this process was relatively stable, and the differences in the topography of Lisbon between the two epochs (1755 and nowadays) are largely a consequence of the redesign of Lisbon downtown in the aftermath of the earthquake and tsunami, in particular the landfill which occupies most of the area between the coastline and the $10 \mathrm{~m}$ height contour depicted in Fig. 1b. The flood that was observed in 1755 (cf. Baptista et al., 1998a) can give us a view on what to expect if a similar tsunami would happen today. The principal changes made in the riverfront require the modeling of the potential effects of an extremely large tsunami in order to allow the evaluation of the tsunami hazard and to gather the necessary recommendations for tsunami warning, as Portugal is now part of the Intergovernmental Coordination group for the implementation of NEAMTWS.

In this paper, we use a deterministic scenario to produce tsunami inundation maps designed to correspond to the worst-case scenario in the Lisbon area. In the absence of an unequivocal consensus on the area of generation and on the rupture mechanism that caused the 1755 earthquake, four earthquake/tsunami scenarios have been chosen by Miranda et al. (2011) as the most sound proposals for an extremely large earthquake in the Gulf of Cadiz area. These scenarios were based upon the results of active fault mapping by several authors (Johnston, 1996; Gutscher et al., 2002; Zitellini et al., 2009) and include the Marquês de Pombal (MP) structure, the Portimão bank (PB) fault, the Horseshoe fault (HS) the Cadiz wedge (CW) and the Gorringe fault (GF).

Previous tsunami simulations by Baptista et al. (2003) and Gutscher et al. (2006) and recent inundation studies in the area used these scenarios (see Omira et al., 2010; Lima et al., 2010) have showed the individual properties of such tsunami sources: the GF fault, located north of the Gorringe bank, radiates most energy towards North America and Morocco; the PB fault being almost parallel to the South Portuguese coast is not effective in producing a devastating tsunami along the west coast of Portugal, where Lisbon is located. The CW is the biggest structure identified in the area which is very effective in radiating energy towards the Strait of Gibraltar, but it seems unable to explain the tsunami observed on the west coast. Also, it produces longer travel times than those observed by an eyewitness of the 1755 event in the near field 
Table 1. Parameters of the Horseshoe Fault (HSF) used here.

\begin{tabular}{llllllll}
\hline Fault & $\begin{array}{l}L \\
(\mathrm{~km})\end{array}$ & $\begin{array}{l}W \\
(\mathrm{~km})\end{array}$ & $\begin{array}{l}\text { slip } \\
(\mathrm{m})\end{array}$ & $\begin{array}{l}\text { Strike } \\
\left({ }^{\circ}\right)\end{array}$ & $\begin{array}{l}\text { Dip } \\
\left({ }^{\circ}\right)\end{array}$ & $\begin{array}{l}\text { Rake } \\
\left({ }^{\circ}\right)\end{array}$ & $M_{\mathrm{W}}$ \\
\hline HSF & 165 & 70 & 15 & 42.1 & 35 & 90 & 8.4 \\
\hline
\end{tabular}

(Gutscher et al., 2006). The two remaining scenarios - HS and MP - are both thrust faults with similar dimensions but with different strikes. The tsunami radiation patterns presented in Omira et al. (2009) clearly show that the HS is more effective than the MP in radiating energy towards the Portuguese west coast. In view of these facts, we selected the HS scenario and scaled it in order to obtain rupture dimensions compatible to an 8.5 earthquake (Solares and Arroyo, 2004) and to produce the $5 \mathrm{~m}$ tsunami wave observed at the castle of Bugio in the 1755 tsunami, according to one of the most detailed eyewitness reports along the Tagus estuary."

Table 1 depicts the parameters of the synthetic earthquake due to the rupture of the Horseshoe fault. The description of the 1755 event by the witness at the castle of Bugio is used as the main benchmark for the tsunami wave.

\section{DEM development}

The Lisbon estuary located approximately $20 \mathrm{~km}$ away from the Atlantic Ocean covers an area of approximately $320 \mathrm{~km}^{2}$ with a mean volume of water of $1.8 \mathrm{~km}^{3}$ (Freire et al., 2006). Its width ranges from 2 to $15 \mathrm{~km}$ and has a mean depth of circa $11 \mathrm{~m}$ (cf. Fig. 1 for location). Ocean water enters the estuary through a deep, narrow inlet channel, $15 \mathrm{~km}$ long and 2-km wide, reaching depths of about $40 \mathrm{~m}$ in some places and trending approximately E-W (see Fig. 1a). The eastern limit of the inlet borders to the south Lisbon riverfront and spreads into an inner bay, about $25 \mathrm{~km}$ long and $15 \mathrm{~km}$ wide, mostly shallow, with a complex bottom topography and numerous channels, inter-tidal flat areas and small islets (Neves, 2010).

Tsunami propagation close to the coast and on land is critically dependent on the small scale effects; so, the DEM (digital elevation model) must be able to represent the most significant coastal features and the shoreline accurately. The digital elevation model, representing the bare earth, was produced to meet the following criteria: (i) homogeneous mapping including the tsunami source area and the test site areas along the coast (ii) good horizontal resolution in the test areas in order to assure a full description of local effects (iii) continuity offshore-onshore in particular in respect to the vertical datum. All data included in the final data set were converted to Cartesian coordinates (UTM29) using datum WGS84. The integration of high resolution depth and elevation data requires a common definition for the vertical reference surface. Bathymetric charts and topographic charts use different vertical references: the first uses a local reference related with the principal harbor of the chart and the second the mean sea surface for a certain epoch. In this project, the zero height (vertical datum) was considered as $2.0 \mathrm{~m}$ above the hydrographic zero as defined by the tide gauge at Cascais (see Fig. 1a). A TIN (Triangular Irregular Network) with all these data points, including the zero height line as constraints and break-lines representing surface discontinuities close to the shoreline (harbor, pier, quay), was constructed. The procedures were similar to those described in Lima et al. (2010), where the accuracy of the grid was evaluated as better than $0.5 \mathrm{~m}$ inland. Offshore the swath bathymetry data has an accuracy depth dependent which can be considered as compatible with on-shore data.

Four levels of topographic grids were prepared with a nesting ratio of 4 ranging from $640 \mathrm{~m}$ to $10 \mathrm{~m}$. The largest one covers approximately the area from $15.2^{\circ} \mathrm{W}, 30.3^{\circ} \mathrm{N}$ to $4.1^{\circ} \mathrm{W}, 39.8^{\circ} \mathrm{N}$, with a grid cell size of $640 \mathrm{~m}$ encompassing the tsunami source area offshore of the Iberian margin. The smallest corresponds to the Tagus estuary along Lisbon riverfront $\left(9.32^{\circ} \mathrm{W}, 38.65^{\circ} \mathrm{N}\right.$ to $\left.9.11^{\circ} \mathrm{W}, 38.73^{\circ} \mathrm{N}\right)$, with a grid cell size of $10 \mathrm{~m}$, the area depicted in Fig. 1b. All grids were computed in rectangular UTM29 coordinates.

\section{Tsunami simulation}

Tsunami propagation and run-up was performed using the code COMCOT-Lx, a modified version of the COMCOT code by Wang and Liu (2006). This is a finite-difference Non-Linear Shallow Water (NLSW) code that uses an explicit leap-frog finite difference scheme to solve the shallow water equations, in a nested grid configuration. It adopts a moving boundary scheme to track the moving shoreline and to reproduce inundation and run-up. NLSW models are considered acceptable for geophysical applications (Synolakis and Bernard, 2006) and recently Arcas and Wei (2011) presented instrumental data that reinforce the above conclusion, although more field data are still needed. The COMCOT model was successfully used to investigate several instrumental tsunami events (e.g. Liu et al., 1994; Wang and Liu, 2007) reproducing well the observations.

To initialize the hydrodynamic model, we use the general approximation in tsunami modeling that considers that the initial free surface deformation equals the static deformation of the seafloor, computed from the parameters of the seismic source, and uses a zero velocity field (Synolakis and Bernard, 2006).

The fact that the tsunami source is far from the study area allows discarding the details on the earthquake source and rupture mechanism. Having this in mind, we focus on the impact of a tsunami with similar wave height observed in 1755 . The common reference between old and modern bathymetry is the Castle of Bugio. In this sense, we set the seismic source to reproduce in the present day bathymetry grid the wave height described in the above-mentioned historical documents. 


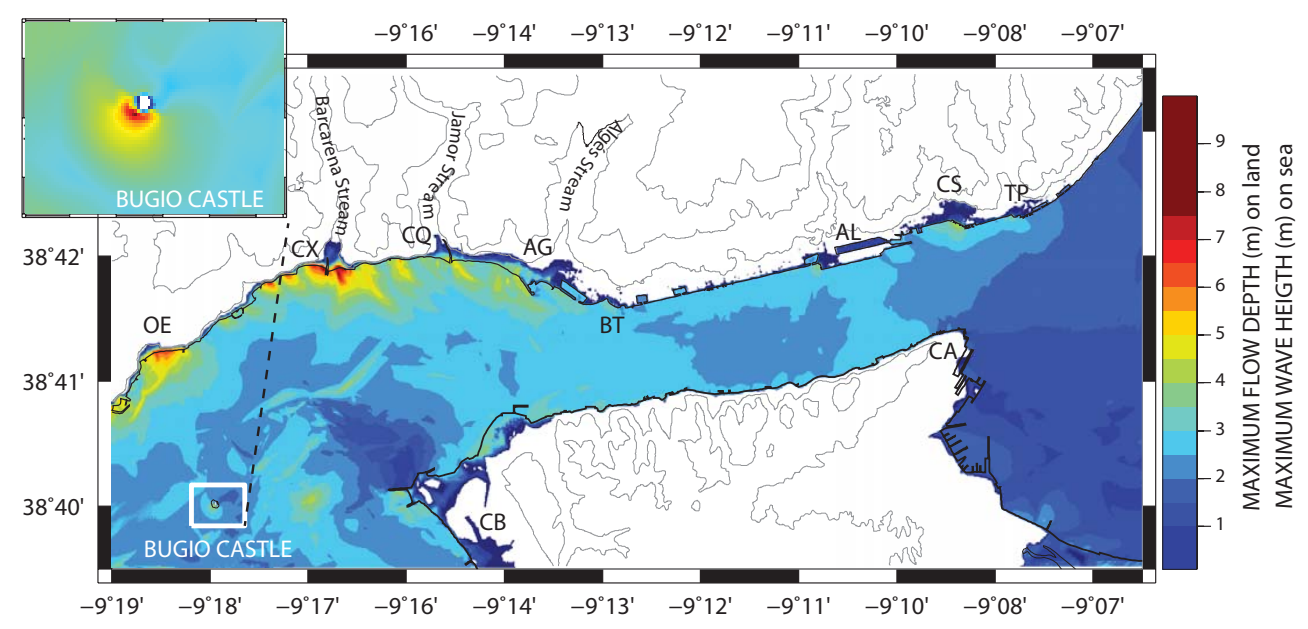

Fig. 2. Maximum flow depth on land for Lisbon Estuary. Offshore maximum wave height is presented. In the inset in the upper left, a zoom is presented concerning the maximum wave height close to Bugio Castle, as reproduced by the $10 \mathrm{~m}$ grid considering the Horseshoe fault model described in Table 1. The small "white out" area corresponds to the upper part of the lighthouse, which was not overtopped by the tsunami. The color scale is the same for both representations. OE: Oeiras; CX: Caxias; CQ: Cruz Quebrada; AG: Algés; BT: Belém Tower (present day position); AL: Alcântara; CS: Cais do Sodré; TP: Terreiro do Paço, CA: Cacilhas; CB: Caparica Beach.

The source parameters used to compute the sea bottom deformation with Mansinha and Smiley (1971) equations, are presented in Table 1. The wave height field close to the Castle of Bugio, as reproduced by the numerical tsunami model in the $10 \mathrm{~m}$ resolution grid, is presented in the inset of Fig. 2, using the same color palette. It can be observed that the maximum wave height is compatible with historical observations.

\section{Inundation areas in Lisbon river front}

From the maximum wave height map presented in Fig. 2, we can immediately conclude that most of the hazardous areas correspond to the intersection of the riverfront by a series of streams, where small beaches do exist, with dense occupation during the summer. Figure 3 shows flow depth and Fig. 4 shows tide reconstitution.

Figure $3 \mathrm{a}$ to $\mathrm{d}$ depicts the wave heights and flooded area between Oeiras and Algés (upstream). Figure 3a to d shows that the wave height in these areas varies from $8 \mathrm{~m}$ at Oeiras towards $4 \mathrm{~m}$ at Algés decreasing upstream. These results agree well with the historical data, Baptista et al. (1998b) present maximum observed wave heights greater than $5 \mathrm{~m}$. The flow depth at Oeiras beach can reach $6 \mathrm{~m}$; the flooding area is limited by the road along the 6-8 $\mathrm{m}$ topographic contours; the maximum inundation distance is circa $200 \mathrm{~m}$. These values are in agreement with the historical report that states that the sea rose more than 30 "palms" (Sousa, 1919), that is approximately $6 \mathrm{~m}$. At Caxias, the Barcarena stream acts as a wave guide and water penetrates until $400 \mathrm{~m}$ inland; flow depth values inland, after the beach, still reach significant values between 2 and $3 \mathrm{~m}$. The historical report, in Sousa (1919), describes that the water entering upstream

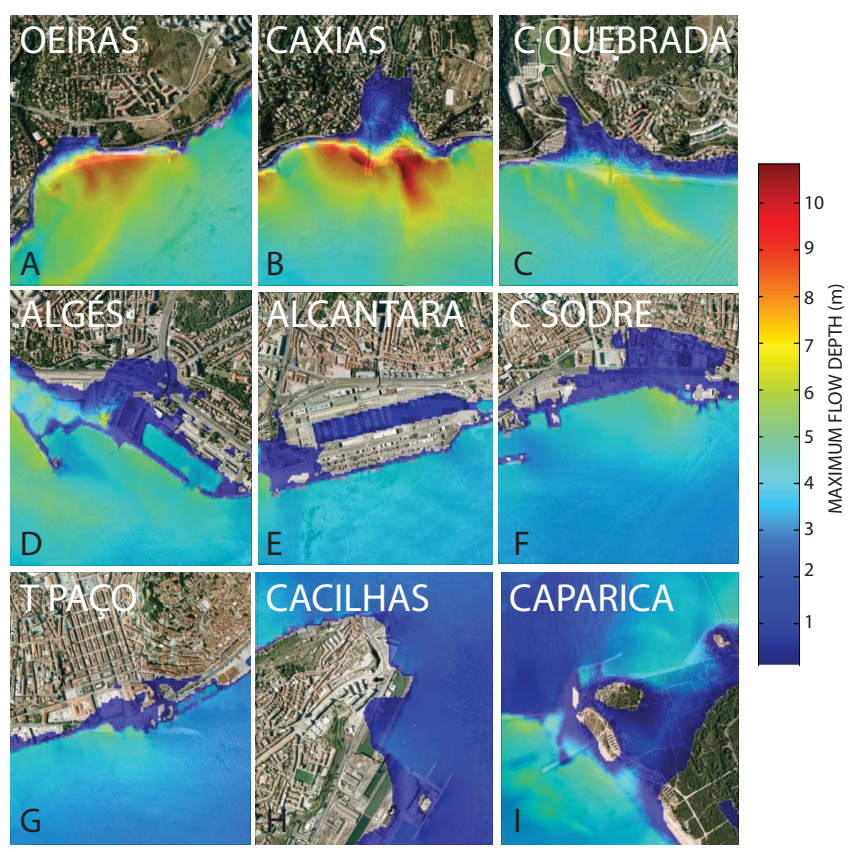

Fig. 3. Inundation areas along the Lisbon riverfront. Offshore, colors represent wave height.

reached the bridge and caused damage, corresponding to the inland limit of Fig. 3b; At C. Quebrada (Fig. 3c), the wave height is significantly lower than in the two former places $3 \mathrm{~b}$ and $3 \mathrm{c}$, and the maximum flow depth is $3-4 \mathrm{~m}$. At Algés, the flood became less intense with a maximum flow depth of $2 \mathrm{~m}$ and damage primarily occurred inside the marina. 

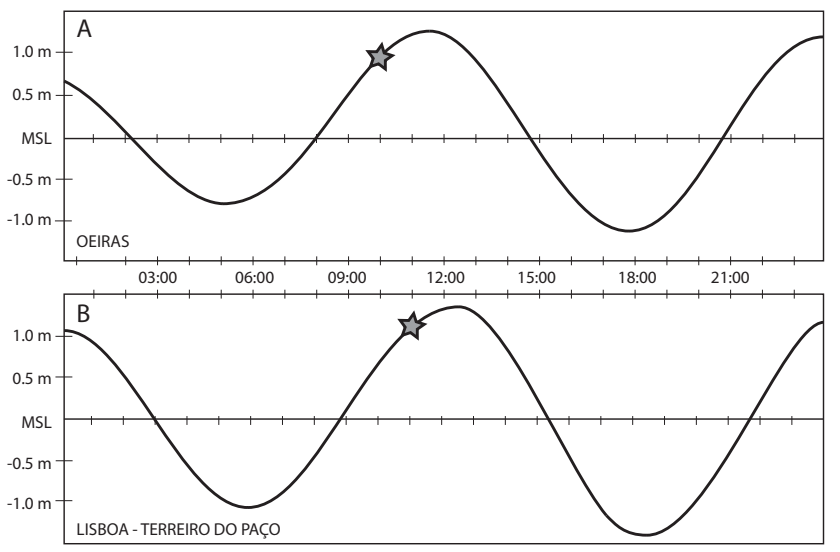

Fig. 4. Tide reconstruction at Oeiras (A) and Terreiro do Paço (B) for the 1 November 1755 tsunami. The star represents the arrival time of the tsunami.

The analysis of Fig. 3a to c shows that the waterways open to the Tagus estuary increase the penetration of the tsunami inland.

Figure $3 e$ to $g$ depicts inundation in downtown Lisbon. These three snapshots show that the maximum wave can reach 6 to $7 \mathrm{~m}$. At Alcântara, (Fig. 3e), most damage would occur in the marina; in C. Sodre the inundation extends further inland with a maximum inundation distance of $350 \mathrm{~m}$; here, the limit is São Paulo Street that follows the $3 \mathrm{~m}$ topographic height; this result is consistent with the report by Mendonça (1758) for the 1755 event.

Figure $3 \mathrm{~g}$ depicts the most important square in Lisbon at the time of the 1755 event. The present day maximum inundation distance in this area is approximately $300 \mathrm{~m}$ with a mean flow depth value between 1 and $2 \mathrm{~m}$. The mean value, $1 \mathrm{~m}$, is approximately the waist height so consistent with the witness account of the 1755 event (Anonymous, 1755).

Inundation at Cacilhas, located inside the estuary on the south bank of the river, is depicted in Fig. 3h; this is the place of the busiest terminal for passenger ferry boats crossing the Tagus daily. In this area, the maximum inundation distance is $250 \mathrm{~m}$ and the mean flow depth is $1.5 \mathrm{~m}$. Sousa (1919) reported some casualties in this area due to the flooding of the river.

Figure $3 \mathrm{i}$ depicts the inundation of the northern section of Caparica, an area of densely populated beaches south of Lisbon. This area is an extremely low area with a maximum topographic elevation of $2 \mathrm{~m}$; thus, it is expected that even a smaller tsunami would flood the area. The average wave height approaching the beach is $6 \mathrm{~m}$ and the flow depth values can reach $2 \mathrm{~m}$.

The computation of overland flow velocities is beyond the scope of this study as it aims only to reconstruct the inundation pattern observed during the 1755 event. Also, we should note that the velocity inland is affected by several factors such as the bottom friction, the bottom slope, inundation

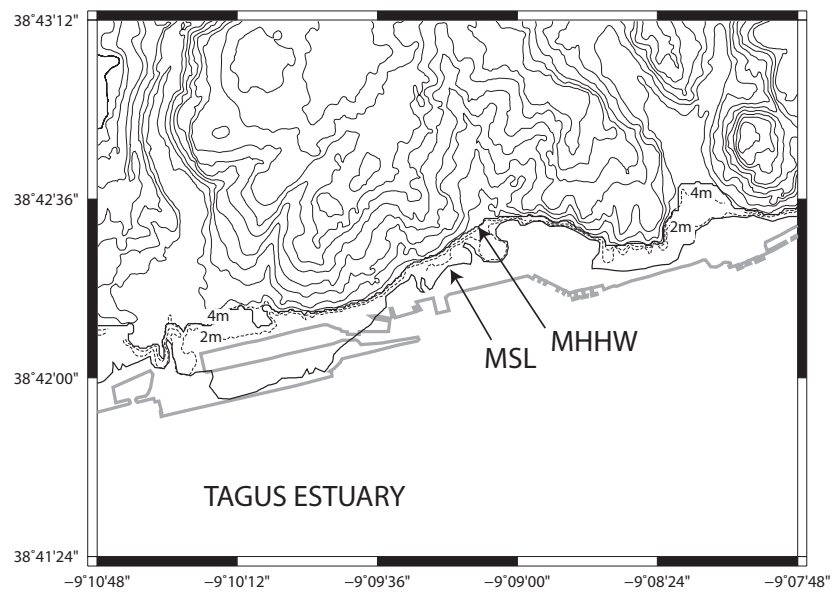

Fig. 5. Comparison of inundation limits for mean sea level (MSL) and Maximum Higher High Water (MHHW) conditions. Height contours are plotted every $10 \mathrm{~m}$ in solid lines. Height contours of $2 \mathrm{~m}$ and $4 \mathrm{~m}$ are depicted in dashed lines.

depth and water surface slope (Matsutomi and Okamoto, 2010).

The overland flow predicted by the model was computed with no bottom friction (0.0 Manning's coefficient) and on bare land not taking into account natural and artificial barriers. A large part of the flooded area corresponds to flow depths ranging between 5 and $1 \mathrm{~m}$ and velocities are higher than $1.5 \mathrm{~m} \mathrm{~s}^{-1}$ thus exceeding the values for people being able to remain standing derived by Takahashi (2005). In some places, the maximum velocity can exceed $5 \mathrm{~m} \mathrm{~s}^{-1}$.

\section{Tide effects on tsunami run-up}

It is well established that tsunami tide interaction can be locally relevant and that tide effects must not be neglected in tsunami run-up computations (Myers and Baptista, 2001; Weisz and Winter, 2005; Kowalik and Proshutinsky, 2006; Dao and Tkalich, 2007). Even in the case of small amplitude tsunamis, the combination of the tsunami with a higher tide can result in a significant net wave height. As noted by previous studies (e.g. Lima et al., 2010), the tide amplitude at the time of the tsunami directly affects the inundation height and hence the impact of the tsunami on the Atlantic coastal areas of Iberia, where tidal amplitudes can be rather large. This is the case of Lisbon, where the peak-to-peak tidal amplitude reaches $3 \mathrm{~m}$, with variations along the estuary and an average tide amplitude of $2.6 \mathrm{~m}$ (Fernandes, 2005).

To understand the effect of tides on the 1755 inundation, we reconstructed the astronomical tide for the 1st of November 1755 , based on the local transit time of the last full moon of the date and its high-tide delay considering the respective Moon phase calendar. Figure 4 represents the tide reconstruction at Oeiras and Lisbon downtown (Terreiro do Paço); the stars depict the corresponding tsunami arrival time 
Table 2. Historical observations of the tide.

\begin{tabular}{llll}
\hline Place & Time & Tide & Reference \\
\hline Lisbon (Portugal) & 11:00 a.m. & Near High Tide & Wolsall (1756) \\
Torres Vedras (Portugal) & 9:40 a.m. & High Tide & Sousa (1919) \\
Porto Novo (Portugal) & 9:40 a.m. & High Tide & Sousa (1919) \\
Oeiras (Portugal) & 10:00 a.m. & Low Tide & Sousa (1919) \\
Plymouth (UK) & 4:00 p.m. & High Tide & Huxham (1755) \\
Kinsale (Ireland) & 2:00-3:00 p.m. & Near High Tide & Nicola (1755) \\
\hline
\end{tabular}

at Oeiras (Baptista et al., 1998b) and Lisbon (Baptista et al., 1998a). The reported tidal observations are presented in Table 2. We conclude that, at the time of the tsunami arrival at Oeiras and Lisbon (Terreiro do Paço), the tide was filling. In Lisbon, it was $25 \mathrm{~cm}$ below high tide, in agreement with the historical tide observations (Wolsall, 1756). However, the tide amplitude was below average, over a period of neap tides and spring tides, closer to the neap tide. A simplified way to include the tide is to add a constant value to the results of the simulations; we can conclude that the tide would add approximately $1 \mathrm{~m}$ of amplitude to both the flow depth and the run-up height. This compares well with the tsunami inundation area observed in 1755 (Baptista et al., 1998a).

The annual average maximum amplitude in spring tides is around $3.2 \mathrm{~m}$ at Lisbon harbor and $2.8 \mathrm{~m}$ at Oeiras, but in the equinox spring tides the maximum amplitude in average reaches $4.0 \mathrm{~m}$ at Lisbon and 3.5 at Oeiras. The mean higher high water (MHHW) for Lisbon is $2.42 \mathrm{~m}$ above mean sea level. So, the tsunami model was run for MHHW conditions and the comparison between the two tsunami inundation areas is depicted in Fig. 5 for Lisbon downtown. When the inundation reaches the slope change that marks the hilly topography of the city, there is no major change on the inundation area, while the run-up is higher. In shallow areas, which is the case of the Terreiro do Paço, the tsunami inundation area is considerably larger. Figure 5 shows that the run-up follows approximately the $2 \mathrm{~m}$ high contour for MSL conditions and the $4 \mathrm{~m}$ high contour for the MHHW conditions.

\section{Discussion and conclusions}

The analysis of these results must take into consideration that modeling resolution is limited by the accuracy of bathymetry and topographic data.

The inundation depths and flow velocities presented here were computed without inclusion of bottom friction; this fact can overestimate the inundation parameters but, on the other hand, they may be used as indicators of the worst case scenario. In spite of these limitations, the results presented here allow the identification of the most vulnerable areas that should be evacuated in case of a major tsunami.

The economic losses due to the 1755 tsunami were very large. Since then, the Tagus Estuary has suffered intense morphological changes due to regularization of the waterfront, construction of commercial and industrial facilities and recreational docks. In particular, the whole Lisbon downtown was rebuilt after the 1755 event to protect the city downtown from tides and even tsunami events, changing not only the conditions for tsunami propagation and run-up but also the location and level of protection of the assets at risk. Nowadays, the average height of the quays and piers along the riverfront is close to $3 \mathrm{~m}$ above mean sea level, while most of the area was covered with sandy beaches at the time of the 1 November tsunami in 1755.

The design of the tsunami scenario used in this study aimed to replicate the best historical observations at the entrance of the Tagus estuary in the 1755 event. It corresponds to the total rupture of the Horseshoe fault with a mean slip of $15 \mathrm{~m}$, which is a reasonable assumption. The flow depths reach maximum values of $1.5 \mathrm{~m}$ in certain areas. Other areas along the estuary display also significant wave heights thus showing that significant inundation can occur in case of a future event. These areas correspond to high density populated areas including sandy beaches, recreational marinas and infrastructures, thus increasing the risk of tsunami.

If we consider that the simplest way to include the tide effect in tsunami modeling studies is to assume linear coupling between tide and tsunami (Mofjeld et al., 2007), we can simply add $1 \mathrm{~m}$ (cf. Fig. 4) to the maximum flow depths presented in this paper to describe a particularly damaging tsunami in Lisbon downtown, in close agreement with historical descriptions. However, the mean higher high water is $2.42 \mathrm{~m}$ above mean sea level, this corresponds to run-up heights close to $4 \mathrm{~m}$ at the Lisbon waterfront. Predicted velocities are, in most of the inundation areas, higher than $1.5 \mathrm{~m} \mathrm{~s}^{-1}$, with inundation depths between $0.5-1.5 \mathrm{~m}$. This result is a clear indication of how difficult it would be for people to escape a tsunami.

Does the 1755 event correspond to the worst case tsunami scenario? Given the magnitude attributed to the earthquake and the length of the historical record, one can consider it as the largest event known. However, due to the high range between spring tides and neap tides, the flood parameters observed during the 1755 tsunami do not represent the worst case scenario: a similar tsunami combined with higher tidal amplitude could even increase the impact in Lisbon downtown. 
Acknowledgements. The authors acknowledge the Municipality of Lisbon, the collaboration of Eng. Marcia Muñoz and her team and their support in the development of the project Avaliação de Riscos Naturais e Tecnológicos na Cidade de Lisboa, funded by FEDER, QREN, POR Lisboa and FFCUL. This work is part of the research projects funded by FCT, Portugal: KINEMA - PTDC/CTEGIN/82681/2006 and Tagus Delta - PTDC/MAR/113888/2009. The authors wish to thank Alberto Armigliato and the anonymous referee for their constructive criticisms which greatly improved the manuscript.

Edited by: S. Tinti

Reviewed by: A. Armigliato and another anonymous referee

\section{References}

Anonymous: Anonymous Letter, Lisbon Nov. 18th 1755, in: The Lisbon earthquake of 1755, Ed. Lisóptima, Lisboa, Portugal, 157-189, 1755.

Arcas, D. and Wei, Y.: Evaluation of velocity-related approximations in the non-linear shallow water equations for the Kuril Islands, 2006 tsunami event at Honolulu, Hawaii, Geophys. Res. Lett., 38, L12608, doi:10.1029/2011GL047083, 2011.

Baptista, M. A. and Miranda, J. M.: Revision of the Portuguese catalog of tsunamis, Nat. Hazards Earth Syst. Sci., 9, 25-42, doi:10.5194/nhess-9-25-2009, 2009.

Baptista, M. A., Heitor, S., Miranda, J. M., Miranda, P., and Mendes Victor, L.: The 1755 Lisbon tsunami; evaluation of the tsunami parameters, J. Geodynam., 25, 143-157, 1998a.

Baptista, M. A., Miranda, P. M. A., Miranda, J. M., and Mendes Victor, L.: Constrains on the source of the 1755 Lisbon tsunami from numerical modeling of historical data, J. Geodynam., 25, 159-174, 1998b.

Baptista, M. A., Miranda, J. M., Chierici, F., and Zitellini, N.: New study of the 1755 earthquake source based on multi-channel seismic survey data and tsunami modeling, Nat. Hazards Earth Syst. Sci., 3, 333-340, doi:10.5194/nhess-3-333-2003, 2003.

Baptista, M. A., Miranda, J. M., and Luis, J. F.: In Search of the 31th March 1761 Earthquake and Tsunami Source, B. Sei. Soc. Am., 96, 713-721, 2006.

Dao, M. H. and Tkalich, P.: Tsunami propagation modelling a sensitivity study, Nat. Hazards Earth Syst. Sci., 7, 741-754, doi:10.5194/nhess-7-741-2007, 2007.

Fernandes, R.: Modelação Operacional no Estuário do Tejo. MSc thesis, Technical University of Lisbon, 95 pp., 2005 (in Portuguese).

Freire, P., Taborda, R., and Andrade, C.: Caracterização das praias estuarinas do Tejo, in: APRH (Ed.), Proceedings do 8 Congresso da Água, Figueira da Foz, CD-ROM, 2006 (in Portuguese).

Gutscher, M., Malod, J., Rehault, J.-P., Contruci, I., Klingelhoefer, F., Mendes-Victor, L., and Spakman, W.: Evidence for active subduction beneath Gibraltar, Geology, 30, 1071-1074, 2002.

Gutscher, M.-A., Baptista, M. A., and Miranda, J. M.: The Gibraltar Arc seismogenic zone (part 2): constraints on a shallow east dipping fault plane source for the 1755 Lisbon earthquake provided by tsunami modelling and seismic intensity, Tectonophysics, 426, 153-166, doi:10.1016/j.tecto.2006.02.025, 2006.

Huxham, J.: Letter XIV, from John Huxham M.D.F.R.S to Mr. William Watson F.R.S., Philosophical Transactions of the
Royal Society of London, LIX, Part I, 371-373, 1755.

Johnston, A.: Seismic moment assessment of earthquakes in stable continental regions - III, New Madrid, 1811-1812, Charleston 1886 and Lisbon 1755, Geophys. J. Int., 126, 314-344, 1996.

Kowalik, Z. and Proshutinsky, T.: Tide-tsunami interactions, Sc. Tsunami Hazards, 24, 242-256, 2006.

Lima, V. V., Miranda, J. M., Baptista, M. A., Catalão, J., Gonzalez, M., Otero, L., Olabarrieta, M., Álvarez-Gómez, J. A., and Carreño, E.: Impact of a 1755-like tsunami in Huelva, Spain, Nat. Hazards Earth Syst. Sci., 10, 139-148, doi:10.5194/nhess10-139-2010, 2010.

Liu, P. L.-F., Cho, Y.-S., Yoon, S. B., and Seo, S. N.: Numerical simulations of the 1960 Chilean tsunami propagation and inundation at Hilo, Hawaii, Recent Development in Tsunami Research, Edited by: El-Sabh, M. I., Kluwer Academic Publishers, 1994.

Mansinha, L. and Smylie, D. E.: The Displacement Field of Inclined Faults, B. Seis. Soc. Am., 61, 1433-1440, 1971.

Matsutomi, H. and Okamoto, K.: Inundation flow velocity of tsunami on land, Island Arc, 19, 443-457, 2010.

Mendonça, J. M. M.: História Universal dos Terramotos que tem havido no mundo desde que há noticia até ao século presente, Biblioteca Nacional de Lisboa, 264 pp., 1758 (in Portuguese).

Miranda, J. M., Matias, L. M., Terrinha, P., Zitellini, N., Baptista, M. A., Chierici, F., Embriaco, D., Marinaro, G., Monna, S., and Pignagnoli, L.: Marine Seismogenic - Tsunamigenic Prone Areas: The Gulf of Cadiz, In Sea floor observatories, Praxis, available online: http://www.springer.com/?SGWID= 0-102-24-0-0\&searchType=EASY_CDA\&queryText=Seafloor, in press, 2011.

Myers, E. P. and Baptista, A. M.: Analysis of factors influencing simulations of the 1993 Hokkaido Nansei-Oki and 1964 Alaska Tsunamis, Nat. Hazards, 23, 1-28, 2001.

Mofjeld, H. O., González, F. I., Titov, V. V., Angie, J. V., and Newman, J. C.: Effects of Tides on Maximum Tsunami Wave Heights: Probability Distributions, J. Atmos. Ocean. Tech., 24, 117-123, doi:10.1175/JTECH1955.1, 2007.

Neves, F.: Dynamics and hydrology of the Tagus estuary: results from in situ observations, $\mathrm{PhD}$ thesis, University of Lisbon Portugal, available at: http://repositorio.ul.pt/handle/10451/2003 (last access: February 2011), 2010.

Nicola, L.: Letter from L. Nicola to James Simon, Esq, F.R.S.: Letter XXIII, Philosophical Transactions of the Royal Society of London, LIX, Part I, 392-393, 1755.

Omira, R., Baptista, M. A., Matias, L., Miranda, J. M., Catita, C., Carrilho, F., and Toto, E.: Design of a Sea-level Tsunami Detection Network for the Gulf of Cadiz, Nat. Hazards Earth Syst. Sci., 9, 1327-1338, doi:10.5194/nhess-9-1327-2009, 2009.

Omira, R., Baptista, M. A., Miranda, J. M., Toto, E. A., Catita, C., and Catalao, J.: Tsunami vulnerability assessment of Casablanca-Morocco using numerical modelling and GIS tools, Nat. Hazards, 54, 75-95, doi:10.1007/s11069-009-9454-4, 2010.

Solares, J. M. and Lopez-Arroyo, A.: The great historical 1755 earthquake: Effects and damage in Spain, J. Seismol., 8, 275294, 2004.

Sousa, F. L. P.: O terremoto do $1^{\circ}$ de Novembro de 1755 em Portugal e um estudo demográfico, Serviços Geológicos, 4 Vol., 1919 (in Portuguese).

Synolakis, C. E. and Bernard, E. N.: Tsunami science before and beyond Boxing Day 2004, Phil. Trans. R. Soc. A, 2006 364, 
2231-2265, doi:10.1098/rsta.2006.1824, 2006.

Takahashi, S.: Tsunami disasters and their prevention in Japan - Toward the performance design of coastal defences, Proceedings of the International Symposium on Disaster Reduction on Coasts, Melbourne, Australia, 2005.

Urban, S.: The Gentleman's Magazine for the year 1755, printed by: Henry D., Cave, R. St John's Gate, London, 554 pp., 1755a.

Urban, S.: The Gentleman's Magazine for the year 1755, printed by: Henry D., Cave, R. St John's Gate, London, 561 pp., 1755 b.

Urban, S.: The Gentleman's Magazine for the year 1755, printed by: Henry D., Cave, R. St John's Gate, London, 558 pp., 1755c.

Wang, X. and Liu, P. L.-F.: COMCOT User Manual - Version 1.6. NY 14853; available at: http://ceeserver.cee.cornell.edu/ pll-group/doc/comcot_user_manual_v1_6_pdf.2006 (last access: January 2011), 2006.
Wang, X. and Liu, P. L.-F.: Numerical simulations of the 2004 Indian Ocean tsunamis - Coastal effects, J. Earthquake Tsunami, 1, 273-297, 2007.

Weisz, R. and Winter, C.: Tsunami, tides and run-up: a numerical study, in: Proceedings of the International Tsunami Symposium, edited by: Papadopoulos, G. A. and Satake, K., Chania, Greece, 27-29 June, 2005.

Wolsall, R.: An Account of the Earthquake at Lisbon*, Nov. 1. 1755, in: Two Letters from Mr Wolsall, Surgeon, to James Parsons, M.D. F.R.S. Philosophical Transactions of the Royal Society of London, LIX, Part I, 398-407, 1756.

Zitellini, N., Gracia, E., Matias, L., Terrinha, P., Abreu, M. A., DeAlteriis, G., Henriet, J. P., Danobeitia, J. J., Masson, D. G., Ramella, R., Somoza, L., and Diez, S.: The quest for the AfricaEurasia plate boundary west of the Strait of Gibraltar, Earth Planet. Sci. Lett., 280, 13-50, 2009. 